\title{
Sarcocystis spp Prevalence in Camel Meat in Jordan
}

\author{
FK Al-Ani ${ }^{1}$ and $\mathrm{Z} \mathrm{Amr}{ }^{2}$ \\ ${ }^{1}$ College of Applied Sciences, A'Sharqiyah University, Oman \\ ${ }^{2}$ Department of Biology, Jordan University of Science and Technology, Jordan
}

Submission: October 02, 2017; Published: November 10, 2017

*Corresponding author: FK Al-Ani, Biology Unit, College of Applied Sciences, A'Sharqiyah University, Sultanate of Oman, Email: falahkalani@asu.edu.om

Keywords: Sarcocystosis; Sarcocystis cameli; Camels; Jordan

\section{Introduction}

Sarcocystosis caused by Sarcocystis spp is widespread in livestock and has significant economic impact on production of domestic animals as well as public health importance. The parasite has indirect life cycles between two hosts with herbivores as intermediate hosts and carnivores as definitive hosts [1]. The parasite produces tissue cysts in cardiac, striated and smooth muscles of intermediate host. Some Sarcocystis species induce weight loss, general weakness, fever, anorexia, abortion and death in domestic animals [1]. Sarcocystiscameli is the only known species in camels with two different cyst wall: thin-walled and thick-walled cysts. The parasite was first described in camels by Mason [2] in myocardium and esophagus of Egyptian camels. The camels act as intermediate host and becoming infected by ingestion of sporulated oocysts passed in feces of carnivores. Dogs can be infected with S. cameli after ingestion of camel meat, so are important in spreading the infection [3]. Since then the parasite has been reported from almost all of the camel-rearing areas of the world [4]. The parasite has been reported in the United Arab Emirates [5], Egypt [6], Sudan, Iran, Kazakhstan [7], Morocco [8], Saudi Arabia [9], and Iraq [10]. The present paper presents a one year study on the prevalence of sarcosytosis infection in camels in Jordan. Also the study determines distribution patterns of camel Sarcocystis infection in different camel organs.

\section{Materials and Methods}

During a one year period, a total of 97 camels slaughtered at AlRamtha slaughterhouse were examined for camel sarcocystosis. The obtained tissue samples for microscopic investigation included diaphragm, heart, esophagus, and skeleton muscles. Collected specimens were divided in to two portions. One

portion was kept in $10 \%$ formalin for histopathological studies. The second samples was kept in ice-box plastic containers and move to the laboratory for Pepsin-digestion method as described by Dubey et al. and modified by Hamidinejat et al. [11]. The method in summary is done by taking approximately $10 \mathrm{~g}$ of each tissue organ of the examined camels were crushed and digested for $30 \mathrm{~min}$ at $40^{\circ} \mathrm{C}$ in $50 \mathrm{~mL}$ of digestion medium containing $1.3 \mathrm{~g}$ pepsin, $3.5 \mathrm{~mL} \mathrm{HCl}$, and $2.5 \mathrm{~g} \mathrm{NaCl}$ in $500 \mathrm{~mL}$ of distilled water. The digested solution was then centrifuged for $5 \mathrm{~min}$ at $1500 \mathrm{RPM}$. The sediment was smeared on slides, stained by Giemsa stain, and examined at 400X magnification under the light microscope for detection of bradyzoites.

\section{Results}

Table 1: The prevalence of sarcocysts in slaughtered camel according to the months of the year.

\begin{tabular}{|c|c|c|c|c|c|}
\hline Month & \#Camel Examined & \#Camel Infected & \% & $\begin{array}{c}\text { Locations Found the } \\
\text { Cyst }\end{array}$ & Camel Age (Year) \\
\hline Oct & 11 & 0 & 0 & - & \\
\hline Nov & 12 & 2 & 16.6 & Diaphragm & $4 \& 6$ \\
\hline Dec & 10 & 1 & 10 & $\begin{array}{c}\text { Diaphragm, esophagus } \\
\text { muscle, heart }\end{array}$ & 7 \\
\hline
\end{tabular}


Journal of Dairy and Veterinary Sciences

\begin{tabular}{|c|c|c|c|c|c|}
\hline Jan & 8 & 0 & 0 & - \\
\hline Feb & 8 & 0 & 0 & - & - \\
\hline Mar & 4 & 0 & 1 & 12.5 & Diaphragm, esophagus \\
\hline April & 8 & 1 & 5.8 & Diaphragm, esophagus & 5 \\
\hline May & 17 & 0 & 0 & - & 5 \\
\hline June & 5 & 1 & 25 & Diaphragm & 4 \\
\hline July & 4 & 0 & 0 & - & \\
\hline Aug & 7 & 0 & 6.18 & & \\
\hline Sept & 3 & 6 & & \\
\hline Total & 97 & & & \\
\hline
\end{tabular}

The prevalence of microscopic sarcocysts in slaughtered camel is shown in Table 1. Sarcocystisbradyzoites were found by digestion method in 6out of $97(6.18 \%)$ investigated camels at tissue digestion method and 2 out of 97(2.06\%) in histopathological methods. Among different organs diaphragm had the highest infection rate (6.18\%), followed by the esophagus $(3.09 \%)$ and heart $(1.03 \%)$. Also, the infection rate was higher in camels of 4 to 7 years old than younger camels of 1 to 3 years old.

In histopathological sections the sarcocysts were seen embedded between muscle fibers with no inflammation or other evidence of pathological changes around the mature sarcocysts (Figure 1). The morphology of the Sarcosytis reported in this paper of thin wall cyst and most probably Sarcocystiscameli.

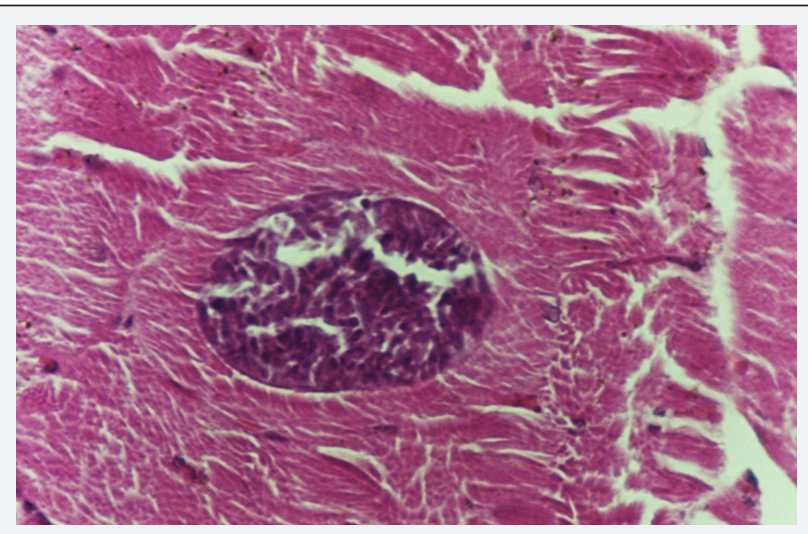

Figure 1: Histopathological section of camel muscle showed Sarcocystis cyst with many compartments filled with zoites (H\&E stain).

\section{Discussion}

In this study, the prevalence of sarcocystosisin camels in Jordan is very low $(6.6 \%)$ comparing to the prevalence of camel sarcocytosisin other countries. The prevalence rate was reported $86.3 \%$ in Iran, 91.6\% in Iraq [12], 66.3\% in Afghanistan [13], $50 \%$ in the United Arab Emirates [14], 88.4\% in Saudi Arabia [15]. This may be due management system when stray dogs are under control and not available in the vicinity of camel herds. Analysis of results on distribution of Sarcocystisin this study in different organs showed higher infection rate in diaphragm and then in the esophagus. Fatani et al. [9] reported diaphragm of camels to be the most common site. Other researchers reported higher incidence in esophagus $[15,16]$, while Shekarforoush et al. [14] found heart as the most infected organ. This predilection differences may be due to different $\mathrm{S}$. cameli strains or definite host origin. There is considerable confusion concerning Sarcocystis species in camels. According to Debby et al. two morphologically distinct sarcocysts have been reported in camels; the thin-walled cysts are generally found in diaphragm, heart and esophagus, while the thick-walled cysts are present only in esophagus. By transmission electron microscopy (TEM) two structurally distinct sarcocysts were recognized by unique villar protrusions not found in sarcocysts from any other host. Sarcocysts of S. cameli had villar protrusions of type $9 \mathrm{j}$. The sarcocyst wall had upright slender villar protrusions, up to $3.0 \mu \mathrm{M}$ long and $0.5 \mu \mathrm{M}$ wide; the total thickness of the sarcocyst wall with ground substance layer was $3.5 \mu \mathrm{M}$. On each villar protrusions, there were rows of knob-like protrusions that appeared to be interconnected. The villar protrusions had microtubules that originated at midpoint of the ground substance and continued up to the tip; microtubules were smooth, without any granules or dense areas. Bradyzoites were approximately $14-15 \times 3-4 \mu \mathrm{M}$ in size with typical organelles. Sarcocystisip penisarcocysts had type 32 sarcocyst wall characterized by conical villar protrusions with an electron dense knob. The total thickness of the sarcocyst wall (from the base of ground substance to villar protrusions tip) was $2.3-3.0 \mu \mathrm{M}$. The villar protrusions were up to $1.2 \mu \mathrm{M}$ wide at the base and $0.25 \mu \mathrm{M}$ at the tip. Microtubules in villar protrusions originated at midpoint of ground substance and continued up to tip; microtubules were crisscrossed, smooth and without granules or dense areas [15-18].

In the present study infection rates risk in higher aged camels was observed [19-26]. Our result is in accordance with Woldemeskel \& Gumi [12] on Ethiopian camels. Higher chance of acquiring infection in older animals has been reported by Shekarforoush et al. [14] in camels.

\section{References}

1. Dubey JP, Hilali M, Van Wilpe E, Calero-Bernal R, Verma SK, et al. (2015) A review of sarcocystosis in camels and redescription of Sarcocystiscameli and Sarcocystisippenisarcocysts from the onehumped camel (Camelusdromedarius). Parasitology 142(12): 14811492. 
2. Mason FP (1910) Sarcocystis in the camel in Egypt. J Comp Pathol Ther 23: $168-176$.

3. Hilali M, Fatani A, Al-Atiya S (1995) Isolation of tissue cysts of Toxoplasma, Isospora,Hammondia and Sarcocystis from camel (Camelusdromedarius) meat in Saudi Arabia. Vet Parasitol 58: 353356.

4. Abdel Ghaffar F, Entzeroth R, Chobotar B, Scholtyseck E (1979) Ultastructural studies of Sarcocystis sp. from the camel (Camelusdromedarius) in Egypt. Tropenmed Parasitol 30(4): 434-438.

5. El-Afifi A, Abden AH, El-Sawah HM (1963) Incidence of sarcosporidiosis in United Arab Emirates. Vet Med J Giza 8: 195-201.

6. el-Etreby MF (1970) Myocaddial Sarcosporidiosis in the camel. Pathol Vet 7(1): 7-11.

7. Kuraev GT (1981) Sarcocystosis of camel, Kzakhstan Sr. Vet Moscow 7: 41 .

8. Kirmse P, Mohanbabu B (1986) Sarcocystis sp. in the one- humped camel (Camelusdromedarius) from Afghanistan. Br Vet J 142: 73-74.

9. Fatani A, Hilali M, al-Atiya S, Al-Shami S (1996) Prevalence of Sarcocystis in camels (Camelusdromedarius) from Al-Ahsa, Saudi Arabia. Vet Parasitol 62(3-4): 241-245.

10. Latif BM, Al-Delemi JK, Mohammed BS, Al-Bayati SM, Al-Amiry AM (1999) Prevalence of Sarcocystis spp. in meat-producing animals in Iraq. Vet Parasitol 84(1-2): 85-90.

11. Hamidinejat H, Hekmatimoghaddam S, Jafari H, Sazmand A, Haddad Molayan P, et al. (2013) Prevalence and distribution patterns of Sarcocystis in camels (Camelusdromedarius) in Yazd province, Iran. J Parasit Dis 37(2): 163-165.

12. Woldemeskel M, Gumi B (2001) Prevalence of Sarcocystis in onehumped camel (Camelusdromedarius) from Southern Ethiopia. J Vet Med B Infect Dis Vet Public Health 48(3): 223-226.

13. Valinezhad A, Oryan A, Ahmadi N (2008) Sarcocystis and Its Complications in Camels (Camelusdromedarius) of Eastern Provinces of Iran. Korean J Parasitol 46(4): 229-234.

14. Shekarforoush SS, Shakerian A, Hasanpoor MM (2006) Prevalence of
Sarcocystis in slaughtered one-humped camels (Camelusdromedarius) in Iran. Tropical Animal Health and Production 38(4): 301-303.

15. Borrow HA, Mohammed HA, di Sacco B (1989) Sarcocystis in Somali camel. Parassitologia 31(2-3): 133-136.

16. Chhabra MB, Samantaray S (2013) Sarcocystis and sarcocystosis in India: status and emerging perspectives. J Parasit Dis 37(1): 1-10.

17. Fayer R (2004) Sarcocystis spp. in human infections. Clin Microbiol Rev 17(4): 894-902.

18. Fukuyo M, Battsetseg G, Byambaa B (2002) Prevalence of Sarcocystis infection in meat-producing animals in Mongolia. Southeast Asian J Trop Med Public Health 33(3): 490-495.

19. Borrow Hagi A, Mohammed Hassan A, di Sacco B (1989) Sarcocystis in Somali camel. Parassitologia 31(2-3): 133-136.

20. Hilali M, Mohamed A (1980) The dog as the final host of Sarcocystiscameli. Tropenmed Parasitol 31(2): 213-214.

21. Hilali M, Nassar AM, el-Ghaysh A (1992) Camel (Camelusdromedarius) and sheep (Ovisaries) meat as a source of dog infection with some coccidian parasites. Vet Parasitol 43(1-2): 37-43.

22. Hossein H, Seyedhossein H, Hedieh J, Alireza S, Pedram HM, et al. (2013) Prevalence and distribution patterns of Sarcocystis in camels (Camelusdromedarius) in Yazd province, Iran. J Parasit Dis 37(2): 163165.

23. Hussein HS, Warrag M (1985) Prevalence of Sarcocystis in food animals in the Sudan. Trop Anim Health Prod 17(2): 100-101.

24. Kan SP, Pathmanathan R (1991) Review of sarcocystosis in Malaysia. Southeast Asian J Trop Med Public Health 22 Suppl: 129-134. Tappe D, Abdullah S, Heo CC, Kannan KM, Latif B (2013) Human and animal invasive muscular sarcocystosis in Malaysia recent cases, review and hypotheses. Trop Biomed 30(3): 355-366.

25. Valinezhad A, Oryan A, Ahmadi N (2008) Sarcocystis and its complications in camels (Camelusdromedarius) of eastern provinces of Iran. Korean J Parasitol 46(4): 229-234.

26. Kuraev GT (1981) Sarcocystosis of camel, Kzakhstan Sr. Vet Moscow $7: 41$.

\section{Your next submission with Juniper Publishers will reach you the below assets}

- Quality Editorial service

- Swift Peer Review

- Reprints availability

- E-prints Service

- Manuscript Podcast for convenient understanding

- Global attainment for your research

- Manuscript accessibility in different formats ( Pdf, E-pub, Full Text, Audio)

- Unceasing customer service

Track the below URL for one-step submission https://juniperpublishers.com/online-submission.php 